\title{
IMPLEMENTASI PEMBELAJARAN JARAK JAUH SELAMA PANDEMI COVID19 MENGGUNAKAN PLATFORM JITSI PADA INSTITUSI PENDIDIKAN MENGGUNAKAN SERVER UBUNTU
}

\author{
Raditya Faisal Waliulu' ${ }^{1}$; Bernard F.N Lain ${ }^{2}$; \\ I Made Mariasa ${ }^{3}$; Riki ${ }^{4}$; Alberto \\ ${ }^{1}$ Politeknik Pelayaran Sorong
}

\begin{abstract}
Abstrak
Kebijakan pelaksanaan pendidikan daring yang dilakukan oleh sekolah dan juga perguruan tinggi di Indonesia adalah menyikapi pandemi Covid-19 yang melanda hampir seluruh dunia. Kementrian Pendidikan dan kebudayaan RI mendorong penyelenggaraan proses pembelajaran dilakukan dengan daring. Hal ini sesuai dengan Surat Edaran Mendikbud RI nomor 3 tahun 2020 tentang Pencegahan Corona Virus Disease (COVID-19) pada Satuan Pendidikan, dan Surat Sekjen Mendikbud nomor 35492/A.A5/HK/2020 tanggal 12 Maret 2020 perihal Pencegahan Penyebaran Corona Virus Disease (Covid-19). Disamping juga mengikuti edaran dan himbauan dari masing-masing Pemerintah Daerah domisili Perguruan Tinggi.Hal ini menyebabkan maju pesatnya perkembangan media komunikasi WEBRTC, sebuah media teknologu realtime audio/video secara live. Hal ini digunakan bersama dalam sebuah room hingga menjadi teleconference.Penelitian ini membahas teleconference jitsi sebagai fasilitator opensource software. Penggunaan ini diterapkan dengan menggunakan konfigurasi default jitsi meliputi proxy server dan socket.Penerapan dilakukan pada tiga tempat berbeda didaerah kota/kabupaten sorong. Diantaranya diujung kota sorong, daerah saoka; kabupaten sorong, aimas dan kepulauan rajaampat, waisai. Didapatkan hasil yang signifikan sesuai dengan kecepatan internet yang didapatkan. Koresponden menggunakan paket data dan wifi telekomunikasi.
\end{abstract}

\begin{abstract}
The education implementation policy carried out by schools and universities in Indonesia is in response to the Covid-19 pandemic that has hit almost the entire world. The Indonesian Ministry of Education and Culture encourages the implementation of the learning process to be carried out with courage. This is under the Circular of the Minister of Education and Culture of the Republic of Indonesia number 3 of 2020 concerning the Prevention of Corona Virus Disease (COVID-19) in the Education Unit, and the Letter of the Secretary-General of the Minister of Education and Culture number 35492 / A.A5 / HK / 2020 dated March 12, 2020 regarding the Prevention of the Spread of Corona Virus Disease (Covid19). As well as following the circular and appeals from the respective Regional Governments that domicile Higher Education. This has led to the rapid development of the WEBRTC communication media, a real-time live audio / video technology media. It is shared in a room to become a teleconference. This study discusses jitsi teleconferencing as an open-source facilitator software. This usage is implemented using the default configuration including proxy server and socket. The application was carried out in three different places in the city / regency of Sorong. Among them at the end of the city of Sorong, the saoka area; Sorong Regency, Aimas and Rajaampat Islands, Waisai. Obtained significant results according to the internet speed obtained. Correspondents use telecommunication data packages and wifi.
\end{abstract}

Kata Kunci : Pembelajaran Jarak Jauh; Pandemi Covid19; Platform Jitsi Server Ubuntu 


\section{PENDAHULUAN}

\section{Latar Belakang}

Selama covid19 atau biasa disebut Corona Disease 19 dikenal dengan nama ilmiah SarCov-2. Kehadirannya di Indonesia awal tahun 2020 merupakan peristiwa yang tidak dapat dihindari. Wabah virus menyebar cepat pada udara dan bersin. Banyak berbagai agenda dalam indsutri ditiadakan hingga mati total.

Selama covid19 industri konvensional tidak dapat beroprasi hingga berkurangnya karyawan besar-besaran. Dampak tersebut membuat banyak pelaku indsutri kreatif hingga pejabat pemerintahan mencariide untuk dapat berperan aktif dalam kegiatan perkantoran namun dari rumah atau istirilah yang diberikan Work From Home.

Institusi pendidikan mengggunakan beberapa metode perkuliahan hingga sekolah daring, harapan guru/dosen hingga siswa/mahasiswa tetap mendapatkan hak belajar mengajar dari pihak institusi masingmasing.

Jika dulunya sekolah atau kuliah dilakukan dengan cara konvensional, yakni mengharuskan peserta didik bertemu dan bertatap muka secara langsung. Hal ini sangat tidak efektif dalam segi waktu dan biaya hingga keselamatan jaga jarak. Hingga saat ini institusi pendidikan menggalangkan perkuliahan daring / sekolah daring. Oleh karena itu, Rapat atau diskusi kelompok belajar menggunakan virtual video conference.
Teknologi web video conference ialah teknologi komunikasi tatap muka antar pengguna melalui dunia maya. Menggunakan teknologi web video conference, kita dapat melakukan rapat meski tidak berada pada waktu dan tempat yang sama. Seiring dengan berkembangnya zaman, terdapat beberapa aplikasi yang dapat digunakan untuk melakukan web video conference. Aplikasiaplikasi ini hanya berbeda di fitur yang disediakan dan kualitas.

Banyak provider menyediakan fasilitas video conference yang dapat menampung 100 hingga 1000 peserta secara bersamaan dari yang murah (kualitas biasa) hingga termahal (kualitas premium) diberikan oleh provider masing-masing. Beberapa diantaranya : Google meeting, Zoom, Skype dan lainya.

Tatap muka online banyak sekali vendor yang mengembangkan video conference diantaranya : Zoom, Open meeting, Jitsi dan Online meet google. Pada penelitian ini terfokus pada program Free Open Source Community (FOSS) dalam bidang teknologi web conference menggunakan Jitsi web confrence. Jitsi merupakan salah satu video confrence opensource yang dapat digunakan selayaknya vendor lainnya.

Kebijakan pelaksanaan pendidikan daring yang dilakukan oleh sekolah dan juga perguruan tinggi di Indonesia adalah menyikapi pandemi Covid-19 yang melanda hampir seluruh dunia. Kementrian Pendidikan dan kebudayaan RI mendorong penyelenggaraan proses 
pembelajaran dilakukan dengan daring. Hal ini sesuai dengan Surat Edaran Mendikbud RI nomor 3 tahun 2020 tentang Pencegahan Corona Virus Disease (COVID-19) pada Satuan Pendidikan, dan Surat Sekjen Mendikbud nomor 35492/A.A5/HK/2020 tanggal 12 Maret 2020 perihal Pencegahan Penyebaran Corona Virus Disease(Covid-19). Disamping juga mengikuti edaran dan himbauan dari masing-masing Pemerintah Daerah domisili Perguruan Tinggi.

\section{Tujuan Penelitian}

Bagaimana implementasi perkuliahan jarak jauh yang mudah cross platform iOS android, low latency, bandwidth sedikit, keamanan data dan integritas peserta aman dari pencurian data menggunakan jitsi.

\section{TINJAUAN PUSTAKA}

\section{State Of The Art}

Penelitian ini berdasarkan pada pokok penerapan Jitsi dilapangan dan penerapan pada perkuliahan atau pembelajaran daring.

Free Open Sertificate bertujuan situs yang diberikan sertifikat aman dari aktivitas sniffing serta terencrypt data. Selain itu, jalur terenkripsi yang berfungsi mengamankan website dan web browser. Perbedaan dasar yang kasat mata dapat dilhat bahwa situs akan memiliki warna hijau pada URL dan memiliki HTTPS (Hypertext.Transfer Protocol Secure)(Manesh, Brijith, Bhraguram, \& Bhadran, 2013).

Jitsi kombinasi platform opensource voice, video confrence, instant messaging yang dapat diakses cross platform Windows, Linux, MacOS, iOS, Android dan windows mobile(Irfan Taufan Asfar \& Akbar Asfar, 2019).

Https membuat semua manjadi situs secure web pada virtualhost. Certbot menghasilkan sebuah key dan certificate files yang digunakan untuk membuat sebuah certificate baru menggunakan Openssl yang telah tersedia di semua macam distro linux. Certbot sendiri merupakan salah satu produk dari SSL Encrypt namun banyak memilih certbot. Selain mudah di customize juga lebih fleksibel serta dapat digunakan pada Apache dan nginx(Vazquez, 2016).

Sistem operasi pada server diberikan adalah Ubuntu 16.04.06 Long Time Support code name Xenial Xerus. Perlu diketahui Ubuntu merupakan salah satu dari turunan distro Debian(Bantun, Ashari, \& Karim, 2020).

Teknologi Informasi adalah solusi dari pemberlakuan perkuliahan secara daring. Banyak media informasi yang digunakan oleh pendidik untuk melakukan pembelajaran secara daring(Lathipatud Durriyah, 2018); (Manca). Pembelajaran selama pandemi adalah e-learning diantaranya Edmodo, Edlink, Moodle, GoogleClassroom.

Ditinjau dari berbagai aspek covid19 atau corona, merupakan musibah yang memberikan dampak negatif hampir dari semua sektor pertumbuhan ekonomi dan sosial. Pembatasan Sosial Berskala Besar (PSBB) atau lockdown dengan berbagai himbauan dirumah saja work from home, 
learn from home, stay home dan lain sebagainya. Namun, dari sisilain hal ini pemicu percepatan proses transformasi digital pendidikan indonesia.

\section{Road Map}

Adapun roadmap ini diberikan kepada Politeknik Pelayaran Sorong agar menjadikan salah satu rencara strategi mengedepankan kelas online sebagai salah satu sumber daya dan mendukung atas sistem ini. Serta memperioritaskan menjadi monitoring evaluasi semester selain cara belajar disisi lain juga mengoptimalkan.

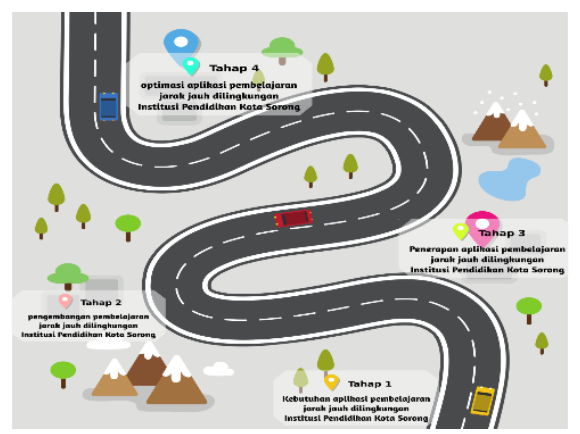

Gambar 1 Roadmap Penelitian

\section{METODE PENELITIAN}

\section{Model Dan Perancangan}

Model perancangan dan penelitian menggunakan kepustakaan dan metode survey. Metode pustakaan dengan mencari surat keputusan pemerintah mengenai pemberlakukan sekolah jarak jauh dari tingkat pendidikan SD, SMP, SMA dan Universitas / Sekolah Tinggi.

Melainkan survey dibuat dan disebar ke siswa/mahasiswa yang menggunakan Jitsi sebagai platform video confrence. Survey yang dilakukan dengan menyebarkan

$$
\text { 4|Jurnal Patria Bahari }
$$

kuisioner menggunakan google form. Hal ini guna menerapkan social distancing oleh pemerintah menanggulangi wabah covid19 serta menerapkan Cloud Computing sebagai wadah pengambilan data jarak jauh. Pengumpulan data primer penelitian ini dengan cara menyebarkan kuisioner ke responden (Creswell,2014)

Data terkumpul dari beragam cara pengumpulan data selanjutnya diolah dan dipadukan untuk mendapatkan interpretasi terkait dengan tantangan, peluang dan ancaman kuliah jarak jauh selama covid19 serta menerapkan teknologi informasi dalam kegiatan pembelajaran online.

\section{Teknik Pengumpulan}

Survey diberikan kepada koresponden peserta didik Siswa, Mahasiswa dan Pasis Politeknik Pelayaran Kota Sorong. Sesuai dengan edaran kementerian Pendidikan dan kebudayaan RI mendorong penyelenggaraan proses pembelajaran dilakukan dengan daring. Hal ini sesuai dengan Surat Edaran Mendikbud RI nomor 3 tahun 2020 tentang Pencegahan Corona Virus Disease (COVID-19) pada Satuan Pendidikan, dan Surat Sekjen Mendikbud nomor 35492/A.A5/HK/2020 tanggal 12 Maret 2020 perihal Pencegahan Penyebaran Corona Virus Disease(Covid19).

\section{Lokasi Penelitian Dan Subjek Penelitian}

Lokasi penelitian pada virtual lab menggunakan jitsi sebagai aplikasi penerapan pembelajaran daring serta responder dari peserta didik institusi 
pendidikan Politeknik Pelayaran Kota

Sorong, SMK N 1 Kabupaten Sorong dan Organisasi Masyarakat.

\section{HASIL DAN LUARAN YANG DICAPAI}

Pembelajaran jarak jauh atau disebut daring, memanfaatkan teknologi begitu juga kuisioner yang digunakan menggunakan google form. Kesiapan pembelajaran daring diterapkan dengan begitu cepat yang semulanya tatap muka offline, secara hasil yang diperoleh dalam penelitian ini diuraikan sebagai beritku :

\section{Tantangan pemanfaatan Teknologi}

\section{Informasi dalam pembelajaran online}

Peserta korespondensi diambil dari 3 Institusi di Kota Sorong dengan total . Tabel menjelaskan peta sebaran korespondensi serta peserta didik yang mengisi kuisioner. Diambil dari 3 perspektif mengenai pembelajaran online dan Work From Home menggunakan jitsi.

\begin{tabular}{|c|c|c|c|c|c|c|}
\hline \multirow[b]{2}{*}{ No } & \multirow[b]{2}{*}{ Lokasi } & \multirow[b]{2}{*}{ Jumlah } & \multicolumn{2}{|c|}{ Perangkat } & \multicolumn{2}{|c|}{ Kualitas video } \\
\hline & & & $\begin{array}{c}\text { Smartp } \\
\text { hone }\end{array}$ & $\begin{array}{c}\text { Laptop/ } \\
\text { PC }\end{array}$ & Laptop & $\begin{array}{c}\text { Smartp } \\
\text { hone }\end{array}$ \\
\hline 1 & $\begin{array}{l}\text { Saoka Kota } \\
\text { Sorong }\end{array}$ & 20 & 15 & 5 & $480 \mathrm{p}$ & $360 \mathrm{p}$ \\
\hline 2 & $\begin{array}{l}\text { Aimas } \\
\text { Kabupaten } \\
\text { Sorong }\end{array}$ & 20 & 10 & 10 & $360 p$ & $480 \mathrm{p}$ \\
\hline 3 & $\begin{array}{l}\text { Rajaampat } \\
\text { Organisasi } \\
\text { Masyarakat }\end{array}$ & 20 & 20 & 0 & $480 \mathrm{p}$ & $360 p$ \\
\hline
\end{tabular}

Kesiapan pembelajaran jarak jauh sangat belum siap terlihat dari data. Kesiapan tidak hanya dari letak geografis juga tingkat pendidikan berpengaruh terhadap hal ini. Semakin tinggi pendidikan semakin cepat mengadaptasikan diri terhadap masalah yang terjadi.
Berdasarkan hasil survey ditemukan sebanyak 30\% mengalami kendala sinyal hilang dan boros pada penggunaan paket data/sinyal wifi. Ketika dilaksanakan pertemuan tatap muka online menggunakan jitsi.

Web RTC atau web conference open source jitsi. Merupakan suatu trobosan dibidang opensource dimasa pandemi. Mengusung web meeting online dapat dilakukan jarak jauh dengan terhubung koneksi internet. Namun, terkendala pada konfigurasi pada sisi server yang mengakibatkan borosnya bandwidth yang dibutuhkan.

Sehingga menyebabkan meeting online terkadang tersendat ataupun delay dari sisi streamer. Selain itu juga spesifikasi server jitsi yang membutuhkan minimal 16GB RAM infrastruktur.Hal ini dikarenakan dari sisi server belum di konfigurasikan secara manual mengenai receive dan sent data, proxy server dan load balanced.

Rata-rata penggunakan laptop mendapatkan kualitas video ada 480p. Artinya koneksi yang menggunakan laptop disesuaikan dengan resolusi laptop bahkan bisa lebih. Serta penggunaan smartphone didapatkan resolusi 360p. Kualitas video stream yang didapatkan oleh smartphone sangat rendah sekali. Namun, hal diatas bisa di lakukan konfigurasi ulang dari sisi server agar bisa dimaksimalkan kualitas video saat conference. 
Peluang pemanfaatan teknolgi informasi dalam pembelajaran online

Transformasi digital disemua sektor mengubah semua substansi hingga mengubah pola kerja dan melejit informasi. Didukung juga regulasi dan upaya konkret menerapkan transformasi digital di lingkungan institusi pendidikan disemua provinsi. Hal ini jelas percepatan industri 4.0 mencapai progress signifikan dari konvensional ke digital pendidikan indonesia.

Video conference menggunakan jitsi pada instansi pendidikan dibutuhkan selain untuk meeting online juga sebagai pembelajaran jarak jauh. Jitsi dan google form sangat efektif sebagai kolaborasi yang pas dalam media pembelajaran selain jitsi platform opensource juga dapat dikembangkan lebih ke arah skala besar diharapkan dari sisi sysadmin dapat ditambah mengenai resource pada server.

\section{RENCANA TAHAPAN BERIKUTNYA}

Rencana tahapan berikutnya, jika dikhendaki dan didukung oleh Politeknik Pelayaran Kota Sorong. Peneliti ingin meninjau lebih dalam mengenai riset mengoptimalkan jitsi dari sisi server dan proxy. Hal ini guna percepatan era digital pendidikan indonesia.

Harapan peneliti, menambahkan pendidikan di era digital dengan manambahkan format pembelajaran dan memasukkannya dalam Rencana Strategi Politeknik Pelayaran Sorong. Sebagai bahan pertimbangan dan dukungan penuh.
Dikembangkannya media meeting online sebagai sarana pembelajaran jarak jauh opensource serta unlimited dalam penggunaan jitsi. Diharapkan di optimalkan jika penggunakan dilakukan oleh hampir 200 partisipant meeting. Selain mengurangi delay video/audio yang diterima juga mengurangi mempercepat dari sisi proxy server.

\section{KESIMPULAN}

Selama covid19 atau corona memberikan sisi dampak positif ataupun negatif pada Institusi pendidikan termasuk pada jenjang pendidikan Politeknik Pelayaran Kota Sorong, SMK Negeri 1 Kabupaten Sorong dan Organisasi Masyarakat yang bertajuk pada pendidikan. Pemberlakukan physical distancing kemudian menjadi dasar pelaksanaan pembelajaran online, diantaranya : Whatsapp group, google classroom, moodle dan lainnya.

Namun ada beberapa kendala yang dialami saat pembelajaran jarak jauh seperti fasilitas jaringan serta mahalnya harga paket data di daerah sorong, papua barat. Berdasarkan hasil survey yang telah diberikan kepada responden, menyatakan belum memiliki laptop, menyatakan susah sinyal dan boros penggunaan paket data. Hal ini disebabkan karena peserta didik yang tinggal jauh dari daerah perkotaan. Pembelajaran online video conference secara langsung sebanyak 95\% peserta didik menyatakan belum pernah menggunakan jitsi sebagai video pembelajaran. 
Rata-rata penggunakan laptop mendapatkan kualitas video ada 480p. Artinya koneksi yang menggunakan laptop disesuaikan dengan resolusi laptop bahkan bisa lebih. Serta penggunaan smartphone didapatkan resolusi 360p. Kualitas video stream yang didapatkan oleh smartphone sangat rendah sekali. Namun, hal diatas bisa di lakukan konfigurasi ulang dari sisi server agar bisa dimaksimalkan kualitas video saat conference.

Konfigurasi yang wajib dilakukan adalah load balancing, proxy server serta tuneup kualitas video agar sreamer dapat dilakukan dengan lancar tanpa delay. 


\section{DAFTAR PUSTAKA}

Bantun, S., Ashari, A., \& Karim, R. (2020). Analisis Kinerja Raspberry Pi Sebagai SIP Server Untuk Aplikasi Video Phone. Semarang: Technocom.

Dewey, K. (2009). Pendidikan Dasar Berbasis Pengalaman. Indonesia: Ipublishing.

El Islami, R. A. (2015). Hubungan Literasi Sains dan Kepercayaan Diri Siswa pada Konsep Asam Basa. Jurnal Penelitian dan Pembelajaran IPA, 1 (1), 16 - 25.

Gunarsa, D. (2004). Psikologi Perkembangan. Anak dan Remaja. Jakarta: Gunung Mulia.

Hamalik, O. (2007). Perencanaan Pengajaran Berdasarkan Pendekatan Sistem (Cet. I). jakarta: Bumi Aksara.

Irfan Taufan Asfar, A., \& Akbar Asfar, A. M. (2019). How To Using Online Meeting On Jitsi Meet Aplication. 1-13.

Livingston, K. C. (2006). Evaluation of the assessment is for learning programe (Cet. I). Glosgow University of Starthcyde.

Malahayati. (2010). Super Teens: Jadi Remaja Luar Biasa dengan 1 Kebiasaan Efektif. (G. G. Center, Ed.)

Manesh, T., Brijith, B., Bhraguram, T. M., \& Bhadran, V. K. (2013). Network Forensic Investigation of HTTPS Protocol. International Journal of Modern Engineering Research (IJMER), 3 (5), 3096 - 3106.

Santrock, J. (2011). Child Development, 11th edition. Jakarta: Erlangga.

Taufik, T. \&. (2013). Kondisi Stres Akademik Siswa SMA Negeri di Kota Padang. Jurnal Konseling dan, 1 (2), 143-150.

Vazquez, A. (2016). Learn CentOS Linux Network Services. Apress, Berkeley, CA.

Wardi, R. \&. (20116). Stress Conditions in Students Completing Thesis. GUIDENA: Jurnal Ilmu Pendidikan, Psikologi, Bimbingan dan Konseling, 6 (2), 190 - 194.

Winataputra, U. d. (2007). Civic Education : Konteks, Landasan, Bahan Ajar dan Kultur Kelas. Bandung: Prodi PKn SPS UPI.

Zola, N. I. (2017). Karakteristik Anak Bungsu. Jurnal Konseling dan Pendidikan, 5 (3), 109 - 114. 